\title{
Assessment of DNA Damage on Adult Albino Rats Induced by Dermal Exposure to P-Phenylenediamine (PPD)
}

\author{
Ahmed AlSeigini, Amany ElSayed, Hend ElHelaly and Eman Abdelhakim ${ }^{1}$
}

${ }^{1}$ Department of Forensic Medicine and Clinical Toxicology, Faculty of Medicine, Ain-Shams University, Cairo, Egypt.

\begin{abstract}
Hair dyes are widely used as cosmetic agents to color the grey hair around the world. Pphenylenediamine (PPD) induced genotoxicity due to dermal application was investigated in this study. 90 rats conducted this study and were classified into main 4 groups. Negative control group, positive control group. In-addition, two toxicity groups; short term toxicity group and long term toxicity group. Both toxicity groups were further subdivided according to PPD dose into 10 and $15 \mathrm{mg} / \mathrm{kg}$ subgroups. The results showed that repeated dermal exposure to PPD induced significant DNA damage in peripheral blood lymphocytes in dose and time dependent manner.
\end{abstract}

\section{Introduction}

$\mathrm{H}$ air dyes are widely used as cosmetic agents to color the grey hair around the world (Denli et al., 2002). P-phenylenediamine (PPD) is used in almost hair dyes preparations regardless of brand. Human exposure to PPD mainly occurs through the skin, but accidental ingestion or inhalation of powdered particles during dyeing process may occur (AbdElzaher et al., 2012). PPD induced toxicity was first reported by Nott and co-workers in 1924 who described the case of a hairdresser who developed toxicity from handling the dye (Gude et al., 2012).

Acute PPD oral toxicity includes: numbness and burning of the mouth and throat, epigastric pain and gastritis, persistent vomiting, dehydration, angioedema, rapid progressive swelling of the lips, tongue, face, eyes, oropharynx and neck (Farrow, 2002). Dermal side effects includes: itching, erythematous scaly plaques, vesicular reactions, angioneurotic oedema, urticaria, anaphylaxis and keloidal reaction (Kang and Lee, 2006). Long-term sequelae include post-inflammatory hypo-or hyperpigmentation, scarring at the tattoo site, and lifelong persistent sensitization. Even after many years, dyeing the hair or eyelashes can result in severe allergic reaction (Jung et al., 2006).

Genotoxicity includes gene mutations, chromosomal aberrations, and DNA effects (Stammberger et al., 2006). Genotoxic causes include: chemicals, diet and exercise, infections and radiation (Cohen and Arnold, 2011)
The study was considered as an exploratory study. Scientific Committee on Consumer Product (SCCP, 2006) reported that the no observed adverse effect level (NOAEL) of PPD is $<5 \mathrm{mg} / \mathrm{kg} /$ day.

\section{Aim of the Work}

The aim of the present study was to assess DNA affection of peripheral blood lymphocytes (PBL) after dermal application in adult albino rats in a dose and time dependent manner.

\section{Materials and Methods}

\section{Chemicals}

The test chemical P-phenylenediamine (PPD), CAS No (106-50-3) was purchased from Sigma Chemical Company in the form of white to light purple powder.

\section{Animals}

Ninety adult albino rats of both sex weighing $(180 \pm 20$ gm b.w.) were housed in stainless steel cages under ambient temperature, $21 \pm 3{ }^{\circ} \mathrm{C}$, and they were acclimatized to the laboratory condition for two weeks.

\section{Experimental design}

I-Animal groups:

Rats were randomly divided into 4 groups as follow:

1- Negative control group: consisting of 20 rats, received nothing but food and water. Rats were further equally sub-divided into 2 subgroups as follow: 
a) Short term group: served as a control for short term toxicity group.

b) Long term group: served as a control for long term toxicity group.

2- Positive control group: consisting of 20 rats in which distilled water was applied topically to the shaved dorsal shaved skin. Rats were further equally sub-divided into two subgroups as follow:

a) Short term group: served as a positive control for short term toxicity group.

b) Long term group: served as a positive control for long term toxicity group.

3- Short term toxicity group: consisting of 20 rats received daily dermal application of PPD for 4 weeks.

4- Long term toxicity group: consisting of 30 rats received daily dermal application of PPD for 12 weeks.

These tested groups were more sub-divided into 2 equal-sub groups according to the applied PPD dose as follow:

- Sub-group: received 10mg PPD/kg/daily.

- Sub-group: received $15 \mathrm{mg}$ PPD/kg /daily.

The study was considered as an exploratory study. Scientific Committee on Consumer Product (SCCP, 2006) reported that the no observed adverse effect level (NOAEL) of PPD is $<5 \mathrm{mg} / \mathrm{kg} /$ day.

All animals were anesthetized using ether inhalation then they were decapitated at the appropriate experimental time. Blood samples from abdominal aorta approximately $10 \mathrm{ml}$ per animal were collected in EDTA tubes protected from light by aluminum foil.

\section{Ethical Consideration}

Ethical approved conditions for animal housing and handling were considered. In-addition, the experimental protocol following the regulations for administration and painless scarification approved by Ethical Committee for Scientific Research- Faculty of Medicine Ain Shams University.

\section{Comet assay (Single Cell Gel Electrophoresis "SCGE"}

Technique: The technique was done according to Singh et al. (1988).

\footnotetext{
Analysis

Electrophoresis cells once stained with Ethidium bromide stain were typically visualized with a fluorescent microscope equipped with a camera. The fluorescence of the Comet tail represented DNA that had migrated outside of the head region due to fragmentation. Fluorescent intensity continued to increase as more DNA migrates into the tail. Computerized image analysis for DNA damage; Comet score software scoring system was used to quantify the
}

degree of damage revealed by the comet assay. Typical measurements were as follow:

Tail Length (TL): Length of the comet tail measured from right border of head area to end of tail (in pixels).

Tail DNA\%: Percent of DNA in the comet tail.

Tail Moment (TM): Tail DNA\% (x) Tail length (Bhat et al., 2013).

\section{Statistical Analysis}

All data were presented as mean \pm standard deviation (SD). Statistical Analysis was performed by two factors ANOVA test and post hoc tukey tests. A p value $<0.05$ was taken into consideration for determining significance. All statistical procedures were computed using SPSS 10.0 software.

\section{Results}

Tables (1, $2 \& 3$ ) and Figs. (1, 2\& 3) showed two factors ANOVA statistical analysis of Comet measurements (tail length, tail DNA\% and tail moment) in control groups (negative and positive), and tested groups (short term and long term).There were non-significant differences between control groups (negative and positive) regarding the mean tail length, tail DNA\% and tail moment. This was declared in figures (4a \&b), which showed a comet image (Fig. 4 a) of peripheral blood lymphocytes (PBL) observed under fluorescent microscope for cells of control groups in which, DNA is tightly compressed and maintains the circular disposition of normal nucleus in most cells of animals belong to control group (Fig. 4 b).

However there were significant increase of tail length, tail DNA\% and tail moment in both tested groups (short term and long term groups) when compared to control group in both doses as shown in images (Fig. 5, 6, $7 \& 8$ ). In which short term toxicity groups showed the comet had rounded head with apparent tail pattern. For those animals exposed to 10 $\mathrm{mg} / \mathrm{kg}$ their cells had short tail pattern, while those animals exposed to $15 \mathrm{mg} / \mathrm{kg}$ had slightly long tail pattern as shown in images (F.g. 5\& 6)

Moreover, images (Fig. $7 \& 8$ ) showed that long term toxicity group had more long tail pattern and that was more evident in cells of those animals exposed to higher PPD dose of $15 \mathrm{mg} / \mathrm{kg}$. Besides, the nuclear head of these animals cells became irregular not rounded indicating that severe DNA affection images (Fig. 8 a \& 8 b).

In-addition, the tables showed presence of interaction between the studied doses of PPD and duration of use, which means that the DNA damage at different doses of PPD depends on duration of treatment and vice versa. By applying HSD there were significant differences of tail length, tail DNA\% and tail moment between short term and long term groups in a dose and duration dependent manner. 
Table (1): Two factors ANOVA statistical analysis of Comet tail length control groups (negative and positive), short term group, long term group, (10 mg, $15 \mathrm{mg}$ sub groups).

\begin{tabular}{|c|c|c|c|c|c|c|}
\hline $\begin{array}{lr}\begin{array}{r}\text { Duration } \\
\text { groups }\end{array} \\
\text { Dose groups }\end{array}$ & $\begin{array}{l}\text { Short term } \\
\text { group } \\
\text { Mean } \pm \text { SD } \\
\end{array}$ & $\begin{array}{l}\text { Long term } \\
\text { group } \\
\text { Mean } \pm \text { SD } \\
\end{array}$ & ANOVA & $\begin{array}{l}\text { Factor } 1 \\
\text { duration }\end{array}$ & $\begin{array}{c}\text { Factor } 2 \\
\text { dose }\end{array}$ & $\begin{array}{c}\text { Interaction } \\
\text { factor } \\
1 \times 2 \\
\end{array}$ \\
\hline Negative control group & $17.32 \pm 8.74$ & $18.8 \pm 10.07$ & $\mathrm{FC}$ & 52.56 & 100.34 & 14.23 \\
\hline Positive control group & $18.00 \pm 9.14$ & $17.83 \pm 8.51$ & FT & 3.85 & 2.622 & 2.622 \\
\hline sub- group $10 \mathrm{mg}$ & $23.89 \pm 9.46$ & $35.1 \pm 11.82$ & $\mathrm{P}$ & $<0.0001$ & $<0.0001$ & $<0.0001$ \\
\hline sub- group $15 \mathrm{mg}$ & $29.41 \pm 12.13$ & $42.5 \pm 12.13$ & HSD & 1.74 & 3.24 & 5.41 \\
\hline
\end{tabular}

$F C=$ calculated $F, F T=$ Tabulated, $H S D=$ Honest significant difference, $P<0.05=$ significant, $P>0.05=$ non- significant

Table (2): Two factors ANOVA statistical analysis of comet tail DNA\% in control groups (negative and positive), short term group, long term group, (10 mg, 15mg sub groups).

\begin{tabular}{|l|c|c|c|c|c|c|}
\hline $\begin{array}{c}\text { Duration } \\
\text { groups }\end{array}$ & $\begin{array}{c}\text { Short term } \\
\text { group } \\
\text { Mean } \pm \text { SD }\end{array}$ & $\begin{array}{c}\text { Long term } \\
\text { group } \\
\text { Mean } \pm \text { SD }\end{array}$ & ANOVA & $\begin{array}{c}\text { Factor 1 } \\
\text { duration }\end{array}$ & $\begin{array}{c}\text { Factor 2 } \\
\text { dose }\end{array}$ & $\begin{array}{c}\text { Interaction } \\
\text { factor 1×2 }\end{array}$ \\
\hline Negative control group & $1.77 \pm 1.03$ & $1.86 \pm 1.27$ & FC & 110.3 & 263.11 & 42.68 \\
\hline Positive control group & $1.65 \pm 0.76$ & $1.59 \pm 0.92$ & FT & 3.85 & 2.622 & 2.622 \\
\hline sub- group 10 mg & $3.22 \pm 1.19$ & $4.96 \pm 1.15$ & P & $<0.0001$ & $<0.0001$ & $<0.0001$ \\
\hline sub- group 15 mg & $4.03 \pm 1.92$ & $7.27 \pm 2.12$ & HSD & 0.23 & 0.43 & 0.73 \\
\hline
\end{tabular}

$F C=$ calculated $F, F T=$ Tabulated, $H S D=$ Honest significant difference, $P<0.05=$ significant, $P>0.05=$ non- significant

Table (3): Two factors ANOVA statistical analysis of comet tail moment in control groups (negative and positive), short term group, long term group (10 $\mathrm{mg}, 15 \mathrm{mg}$ sub groups).

\begin{tabular}{|c|c|c|c|c|c|c|}
\hline Dose groups & $\begin{array}{l}\text { Short term } \\
\text { group } \\
\text { Mean } \pm \text { SD }\end{array}$ & $\begin{array}{l}\text { Long term } \\
\text { group } \\
\text { Mean } \pm \text { SD }\end{array}$ & ANOVA & $\begin{array}{l}\text { Factor } 1 \\
\text { duration }\end{array}$ & $\begin{array}{c}\text { Factor } 2 \\
\text { dose }\end{array}$ & $\begin{array}{l}\text { Interaction } \\
\text { factor } 1 \times 2\end{array}$ \\
\hline Negative control group & $0.31 \pm 0.24$ & $0.36 \pm 0.32$ & $\mathrm{FC}$ & 178.3 & 264.9 & 68.37 \\
\hline Positive control group & $0.29 \pm 0.2$ & $0.27 \pm 0.2$ & FT & 3.85 & 2.622 & 2.622 \\
\hline sub- group $10 \mathrm{mg}$ & $0.79 \pm 0.5$ & $1.74 \pm 0.76$ & $\mathrm{P}$ & $<0.0001$ & $<0.0001$ & $<0.0001$ \\
\hline sub- group $15 \mathrm{mg}$ & $1.18 \pm 0.78$ & $3.05 \pm 1.16$ & HSD & 0.11 & 0.2 & 0.33 \\
\hline
\end{tabular}

$F C=$ calculated $F, F T=$ Tabulated, $H S D=$ Honest significant difference, $P<0.05=$ significant, $P>0.05=$ non- significant

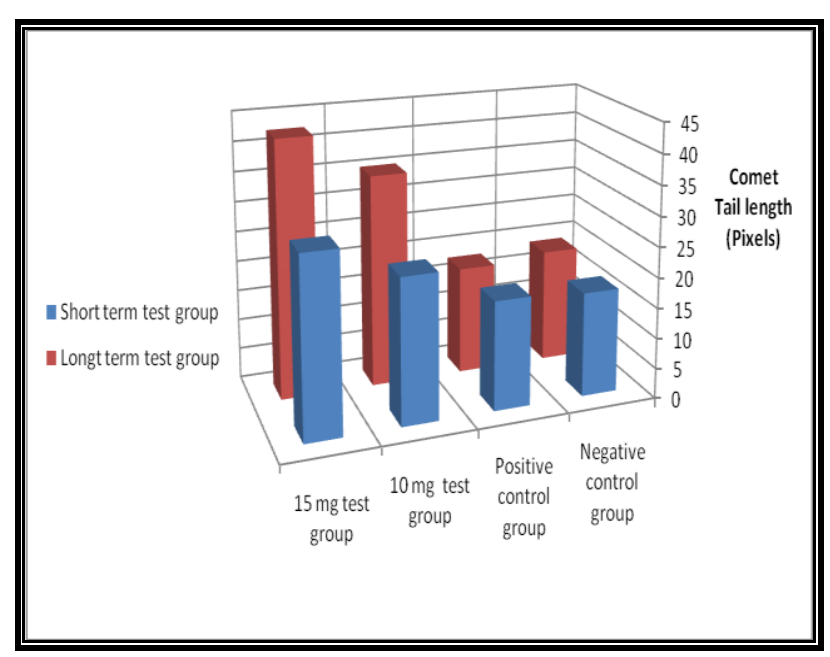

Fig. (1): Comet tail length of both short and long term groups.

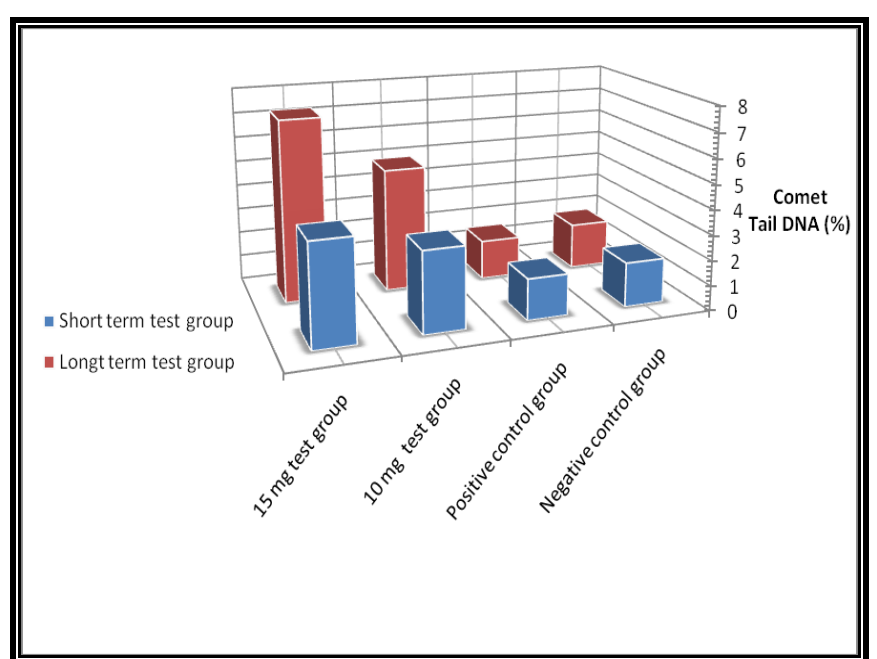

Fig. (2): Comet tail DNA\% of both short and long term groups. 


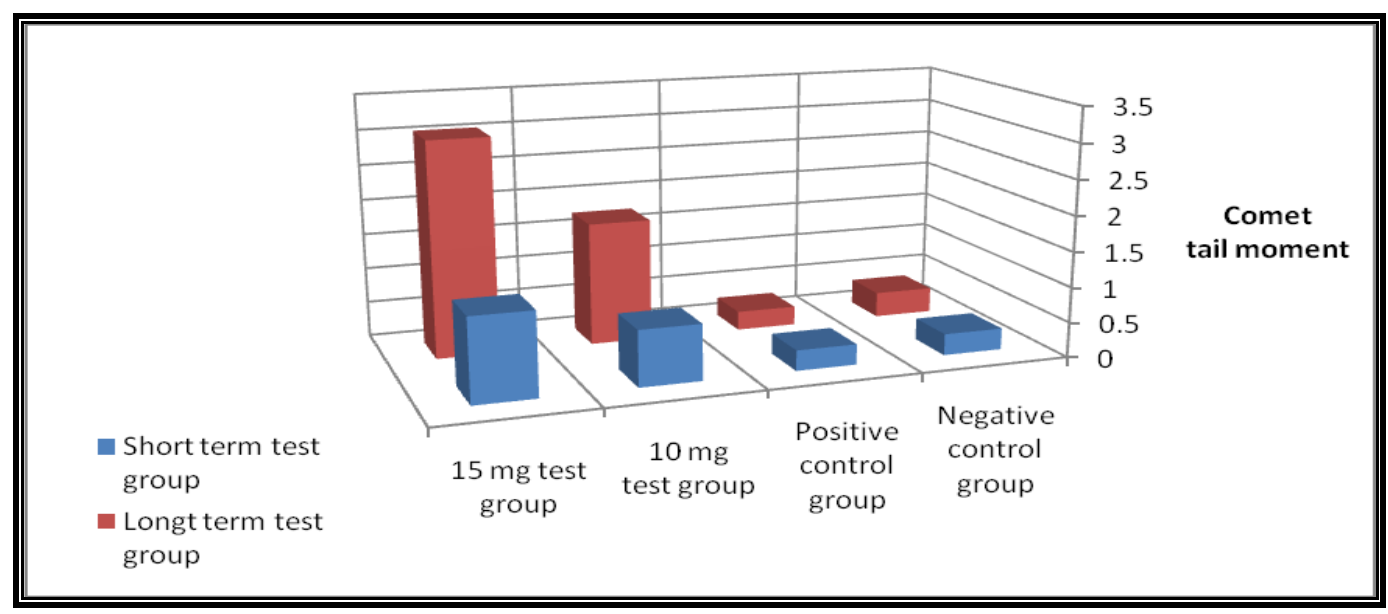

Fig. (3): Comet tail moment of both short and long term groups.

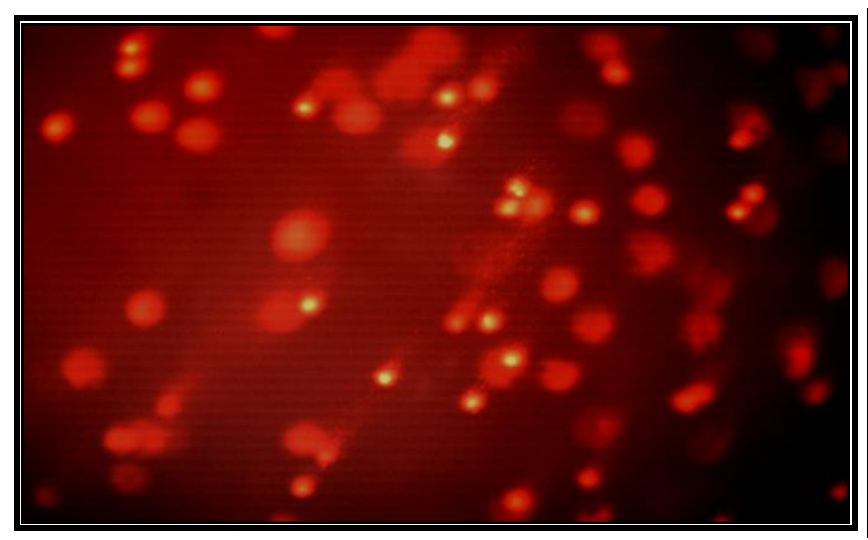

Fig (4.a): Comet image of a rat peripheral blood lymphocytes (PBL) observed under fluorescent microscope. Control group: in most cells the DNA is tightly compressed and maintains the circular disposition of normal nucleus.

(Ethidium bromide X 200).

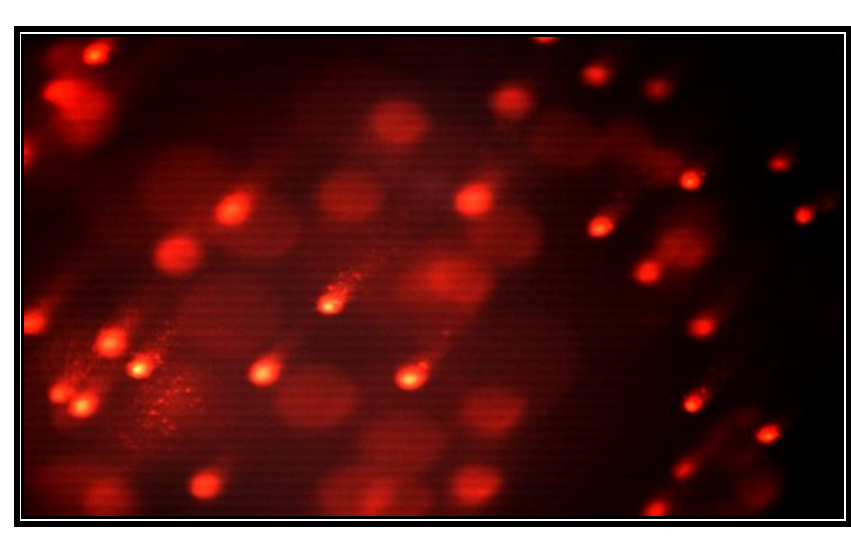

Fig (5): Comet image of a rat PBL observed under fluorescent microscope. Short term $10 \mathrm{mg}$ sub group. The Comet has rounded head and short tail pattern. (Ethidium bromide X 200).

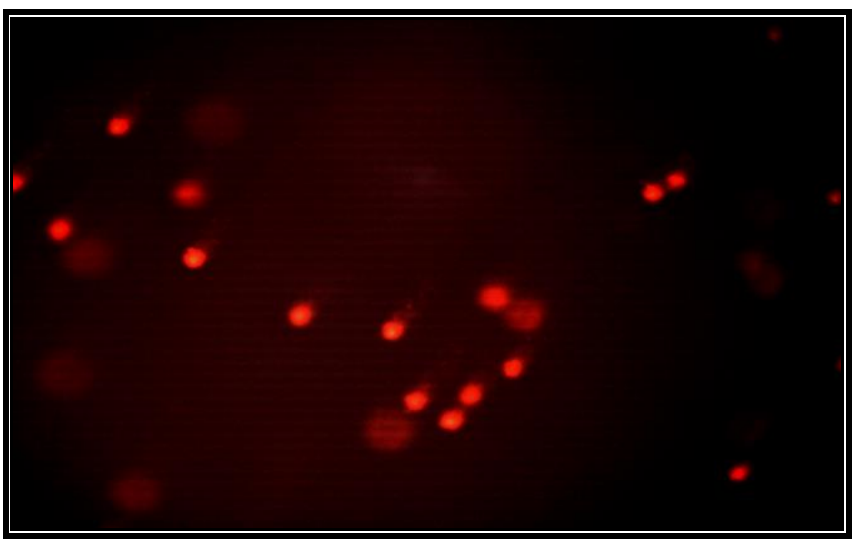

Fig (4.b): Comet image of a rat PBL observed under fluorescent microscope Control group: in most cells the DNA is tightly compressed and maintains the circular disposition of normal nucleus (Ethidium bromide X 200).

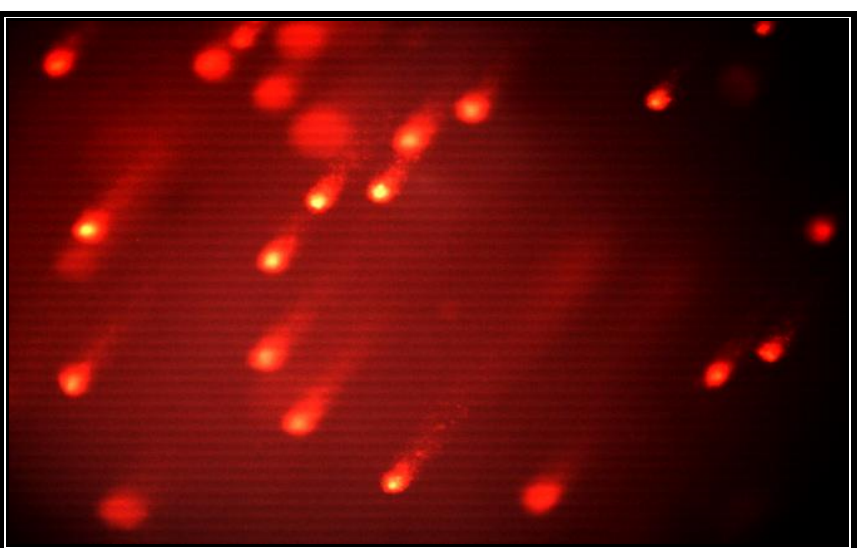

Fig (6): Comet image of a rat PBL observed under fluorescent microscope. Short term $15 \mathrm{mg}$ sub group. The Comet has rounded head and slightly long tail pattern. (Ethidium bromide $X \mathbf{2 0 0}$ ). 


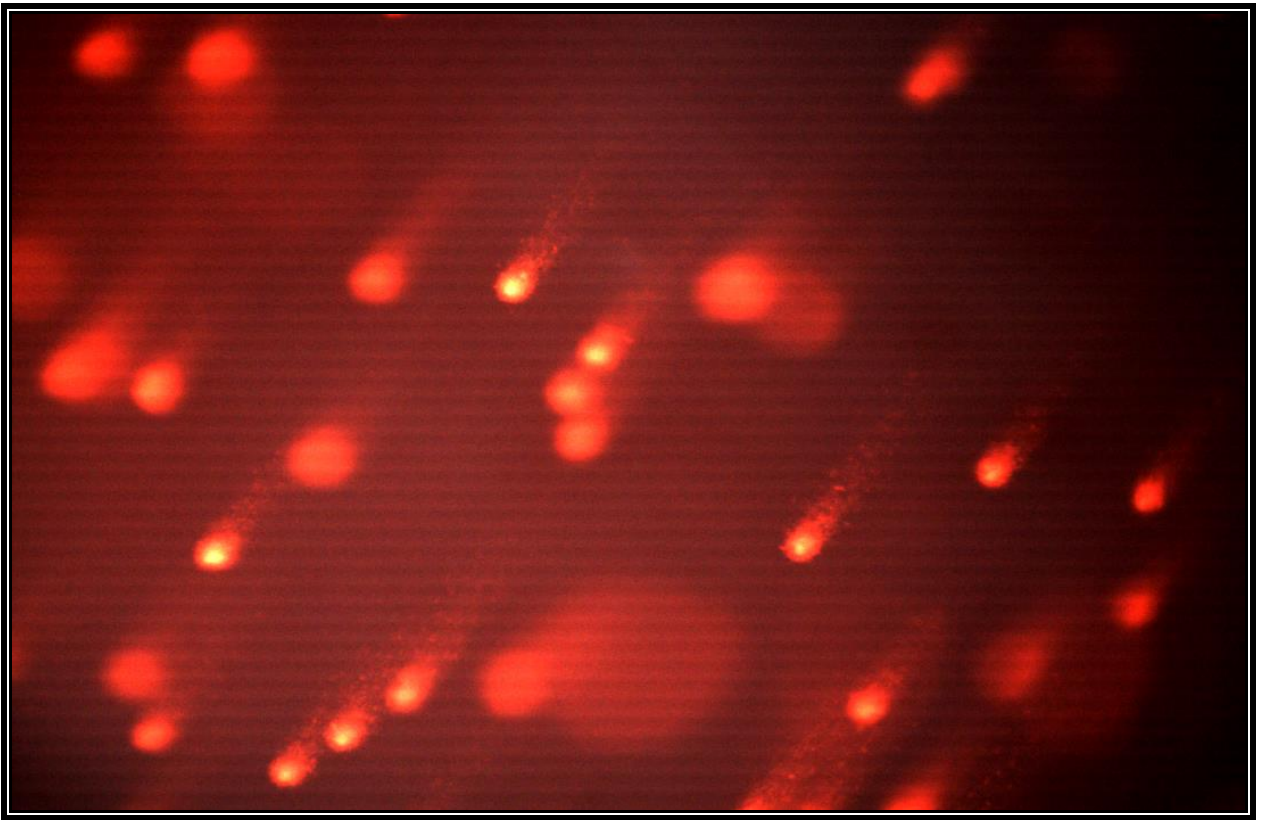

Fig (7): Comet image of a rat PBL observed under fluorescent microscope. Long term $10 \mathrm{mg}$ sub group. The Comet has rounded head and the tail is longer than the other previous patterns indicating that DNA damage is more severe.

(Ethidium bromide X 200).

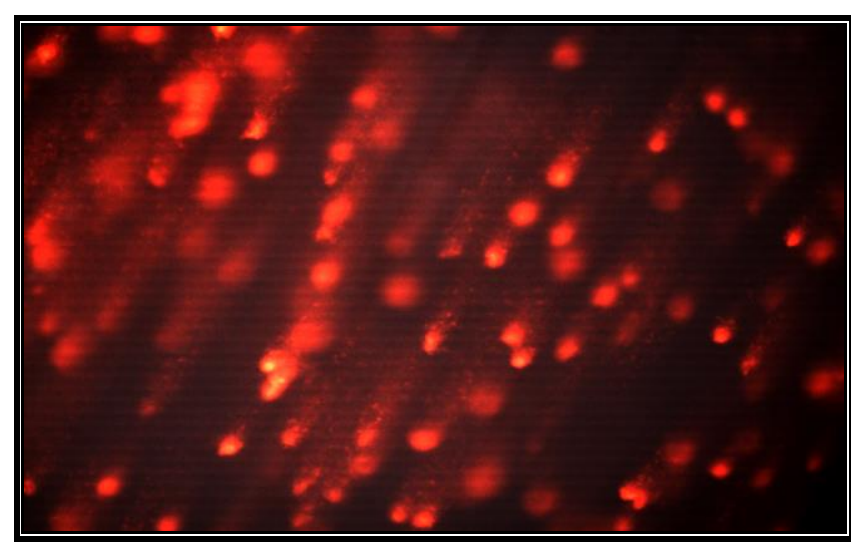

Fig (8.a): Comet image of a rat PBL observed under fluorescent microscope. Long term 15 mg sub group. Residual irregular head and long granular tail, since most DNA migrated to tail.

(Ethidium bromide $X$ 200).

\section{Discussion}

P-phenylenediamine (PPD) is a very common ingredient in most of the hair dye preparations. It accelerates the dyeing process and may produce local as well as systemic toxic effects when applied topically or ingested (Sutrapu et al., 2010).

The type and severity of symptoms vary depending on the amount and the nature of exposure (Yoshio et al., 2003). Acute toxicity has been well studied in animals and humans, important clinical manifestations are angioedema leading to respiratory distress, rhabdomyolysis, intravascular hemolysis, acute renal failure and hepatic necrosis (Chaudhary et al., 2013).

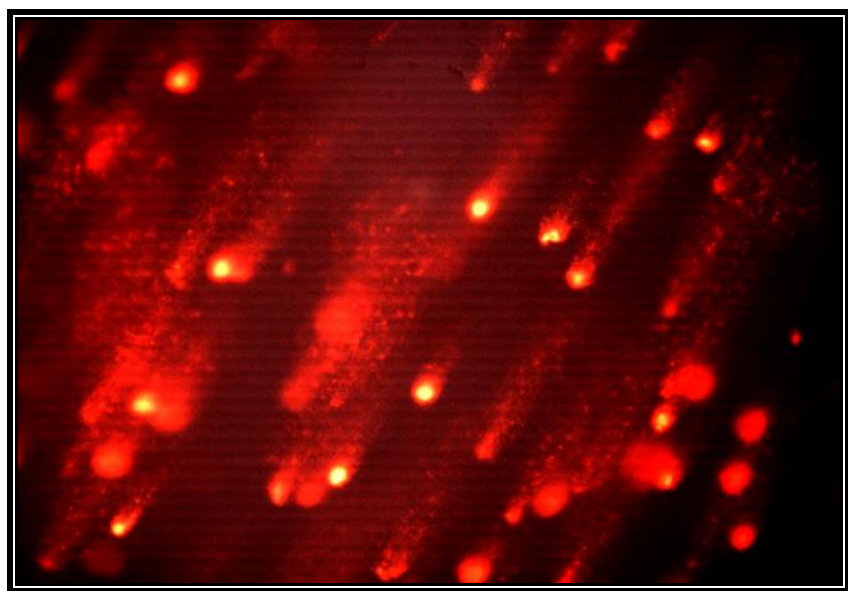

Fig (8.b): Comet image of a rat PBL observed under fluorescent microscope. Long term 15 mg sub group. Residual irregular head and long granular tail, since most DNA migrated to tail.

(Ethidium bromide $X$ 200).

However, reports on the chronic use of PPD are limited. Lethargy, myalgia, anorexia, gastrointestinal disturbances, liver and spleen enlargement, chronic renal failure, progressive neurological symptoms and coma have all been attributed to chronic exposure to PPD (Farrow, 2002).

The pathophysiologic mechanisms by which PPD causes its toxic effect could be explained as PPD is a good hydrogen donor and is metabolized by one electron oxidation to a cation free radical by cytochrome $\mathrm{P} 450$ oxidase to form a reactive benzoquinone. This further oxidized to a trimmer known as Bandrowski's base which is reported to cause anaphylaxis as well as being strongly mutagenic and highly toxic (Ram et al., 2007). However, Chen et al., 
(2010) attributed PPD toxicity to lipid peroxidation and increased free radicals formation which are responsible for the deleterious tissue damage in muscles (skeletal and cardiac) kidney and liver. The objective of the present study was to assess DNA affection of peripheral blood lymphocytes after dermal application in adult albino rats in different doses and durations.

The current study showed that PPD is a genotoxic substance manifested by peripheral blood lymphocytes DNA damage which was evaluated by Comet assay. Densitometric and geometric parameters of the comets as determined using image analysis software revealed that PPD dermal application increased the comet tail length, DNA\% in the tail and tail moment in dose and time dependent manner.

Similar toxic effects were observed by Coulter et al. (2008) and Chen et al. (2010), who reported cell death in human dendritic cells and mardin-darby canine kidney cells (MDCK) respectively. In addition, Chen et al. (2010) reported that cells treated with PPD showed DNA damage up to 3 folds as compared to untreated cells. DNA damage was dose and duration dependent and it was evaluated by Comet and Terminal deoxynucleotidyl transferase (TdT) dUTP Nick-End Labeling (TUNEL) assays. Moreover, Bharali and Dutta (2010), stated that PPD is genotoxic in nature and caused DNA fragmentation of peripheral blood lymphocytes in dose and time dependent manner which evaluated using comet assay after sub-chronic dermal exposure.

In agreement with the current study results, in vitro studies by Elyoussoufi et al. (2013, 2014) reported that PPD is a suspected carcinogen that can induce apoptosis. The aforementioned studies showed that PPD had induced cytotoxicity and cell death in human cultured neutrophils and murine myeloma cells respectively in dose and time of application. Apoptosis was evaluated by light microscopy that revealed nuclear pyknosis and chromatin condensation which are specific morphological changes characteristic of apoptosis. This finding was further confirmed by DNA fragmentation analysis in agarose gel electrophoresis.

In agreement with other human studies, a small but significant increase in mean tail moment was reported by Chye et al. (2008) in 20 female volunteer after oxidative hair dyeing. Galiotte et al. (2008) reported a higher frequency of DNA damage of female hairdressers exposed to oxidative hair dyes compared to control group.

In contrary, according to Sardas et al. (1997) there is no evidence of an increased prevalence of DNA strand breaks or sister chromatid exchanges (SCEs) in peripheral lymphocytes or Salmonellapositive mutagenic activity in the urine of 15 heavily exposed hairdressers who had an extensive history of work without protective measures. This confirmed the results of an earlier studies by Kirkland et al, (1978 and 1981) on female volunteers exposed to up to 13 cumulative hair dye applications including PPD with no increased incidence in (SCEs) or chromosome breaks/aberrations in peripheral lymphocytes. These negative results could be explained by the study of
Dressler and Appelqvist (2006) who conducted in vivo metabolism / toxicokinetic studies in two different animal models revealing that topical application of PPD resulted in minimal blood concentration, and no parent compounds were detected in the blood although the studies were performed under maximized exposure conditions.

According to Kawakubo et al. (2000), Nohynek et al. (2004) and Skare et al. (2007), humans after dermal contact with PPD are not systemically exposed to the parent compound but rather to their $\mathrm{N}$ acetylated metabolites that takes place in human skin and is catalyzed by NAT1. N-acetylation represents a detoxifying reaction, which results in non-sensitizing, non-genotoxic and non-carcinogenic metabolites. Nacetylation in the skin explained why those arylamines that are carcinogenic in rodents only via oral route, not dermal one (Meuling and DeBie, 2009).

Moreover, a review of biomonitoring studies measuring genotoxicity in humans exposed to hair dyes reported that there is no consistent evidence of genotoxicity in humans exposed to hair dyes either occupationally or through individual use (Preston et al., 2009). On the other hand, Bharali and Dutta (2011) suggested that repeated exposure conditions to PPD may reduce the detoxifying capabilities of skin and thus exposing the organism to the parent PPD molecule which is genotoxic.

In addition, Kawakubo et al. (2000) attributed the PPD genotoxic effect, that large amount of PPD could be oxidized at skin surface by series of enzymes, such as ceruloplasmin, myeloperoxidase and cytochrome p-450 to benzoquinone diamine which in turn might form Bandrowski's base (BB). It was thought that the reactivity and mutagenicity of PPD increased by the development of such base. This coincided with the study of Txilar (2004) who stated that subjects have been shown to react to metabolic breakdown products of PPD than the actual PPD molecule.

Moreover, Albert and Magee (2000) reported that the electrophilic nature of some contact sensitizers such as PPD and its derivatives was also characteristic of genotoxic tumorigens. Electrophiles could adduct protein, which was the basis for allergic contact dermatitis, as well as DNA damage, which was the basis for mutagenicity and carcinogenicity. Eyer (2002) added that PPD an aromatic amine belonged to a group of compounds that exerted their toxic effects usually after oxidative biotransformation primarily in the liver. PPD also underwent extra hepatic activation to free aminyl radicals. These reactive intermediates were potentially promutagenes and procarcinogenes. Aminyl radicals quickly disproportionate to quininediamine and addition reaction through covalent binding with thiol might result. The quinoid thio-ethers products of sequential oxidation/addition reaction were more toxic than the parent compound because of their higher auto-oxidizability. The quinoid thio-ethers could then cross link protein by addition to neighboring nucleophils with elevated levels of DNA adduct and inhibition of the synthesis of the critical mitochondrial 
proteins and the resultant impairment of nuclear mRNA synthesis and chromosomal damage.

Mathur et al. (2005) explained the observed DNA damage was most likely due to PPD induced oxidative stress and production of reactive oxygen species (ROS). Moreover Filipic et al. (2007) reported that ROS are known to induce DNA strand breaks which can be readily detected by Comet assay. Moreover, Sutrapu et al. (2010) recorded that PPD induced depletion of glutathione. Glutathione (GSH) is a tri-peptide present in mast cells and functions as an antioxidant protecting cells from toxic effects of ROS, in addition to maintenance of cell viability, regulating immune cell functions and plays a vital role in DNA replication. In addition an elevation of malondialdehyde (MDA) marker of lipid suggest a decrease in antioxidant status and an overwhelming oxidative stress supports. This DNA damage was mediated by oxidative stress (Sutrapu et al., 2010)

Furthermore, Chen et al. (2010) PPD induced intracellular generation of ROS initiating both intrinsic (caspase 9) and extrinsic (caspase 8) pathways which converge to activate caspase $3 / 7$ resulting in loss of cell viability and apoptosis. The involvement of ROS in DNA damage was validated by using vitamin $\mathrm{C}$ and $\mathrm{E}$ well known antioxidants-which inhibited ROS generation ( Bharali and Dutta, 2012).

In the same context, Waggas, (2011) stated that ROS are considered to cause DNA damage to cells either by oxidizing lipids in the cell membrane or by direct attacking DNA. Lipid peroxidation affects the physical stability of the membranes, resulting in altered calcium homeostasis, activation of endo-nucleases, sulfhydryl modification of proteins and oxidative DNA damage (Elyoussoufi et al., 2013).

\section{Conclusion}

The study revealed that PPD is genotoxic substance and causes significant DNA damage in peripheral blood lymphocytes. This was evaluated by Comet assay. DNA damage and was significantly manifested among rats exposed to higher doses of PPD (15 mg) and those with longer duration(12 weeks) of PPD application.

\section{Recommendation}

- PPD handlers such as hair dresser, textile manufacturing workers, and chronic tattoo users showed be subjected to serial biochemical and genetic assay follow up.

- They also should have protective measures decreasing chronic hazardous of PPD. Protective gloves, overalls and masks should be provided for those working in photographing manufacturing.

- Further studies of chronic PPD systemic toxicities advised to be accomplishes as well as investigating protective drugs and agents ameliorating such toxicities.

\section{References}

AbdElzaher M A, Fawzy I F, Ahmed H M, et al., (2012): "Some toxicological health hazards associated with subchronic dermal exposure to paraphenylenediamine(PPD): An experimental study". Egyptian Journal of Forensic Sciences, 2: 105-111.

Albert RE and Magee PS (2000): “Tumorgenicity of mutagenic contact-sensitizing chemicals". Risk Analysis, 20: 317-325.

Bhat MA, Mahajan N and Gandhi G (2013): "DNA and chromosomal damage in coronary artery disease patients". EXCLI Journal, 12:872-884.

Bharali MK and Dutta K (2010): "Hematotoxic and genotoxic effect of paraphenylenediamine after subchronic topical application in rats". The Bio scan, 5:585-590.

Bharali MK and Dutta K (2011): “Testicular toxicity of para-phenylenediamine after subchronic topical application in rat". Int J Environ Health Res., 22(3):270-278.

Chaudhary SC, Sawlani KK and Singh K (2013): "Paraphenylenediamine poisoning". Nigerian Journal of Clinical Practice, 16(2):258-259.

Chen SC, Chen CH, Tioh YL, et al., (2010): "Paraphenylenediamine induced DNA damage and apoptosis through oxidative stress and enhanced caspase- 8 and -9 activities in Mardin-Darby canine kidney cells". Toxicol in Vitro, 24: 1197-1202.

Chye SM, Hseu YC, Liang SH, et al., (2008): "Single strand DNA breaks in human lymphocytes exposed to Paraphenylenediamine and its derivates". Bull environs contam toxicology, 80(1): 58-62.

Cohen SM and Arnold LL (2011): "Chemical Carcinogenesis. Toxicological sciences". 120(1):76-92.

Coulter EM, Jenkinson C, Wu Y, et al., (2008): "Activation of T-cells from allergic patients and volunteers bypphenylenediamine and Bandrowski's base". J. Invest Dermatology, 128: 897 905.

Denli M, Dundaroz R, Degim Z, et al., (2002): Effect of long term use of hair dyes on the DNA damage in healthy female subjects. The Medical Journal of Kocatepe, 3: 57-62.

Dressler WE and Appelqvist T (2006): "Plasma/blood pharmacokinetics after dermal exposure to para-aminophenol or para-phenylenediamine". Food Chem. Toxicology, 44: 371-379. 
Elyoussoufi Z, Habti N, Mounaji K, et al., (2013): "Induction of oxidative stress and apoptosis in human neutrophils by $\mathrm{p}$ phenylenediamine". Journal of Toxicology and Environmental Health Sciences, 5(8):142-149.

Elyoussoufi Z, Habti N, Mounaji K, et al., (2014): "Involvement of caspase-8, -9 and -3 in p-phenylenediamine induced apoptosis in murine myeloma p3 cells: regulation by reactive oxygen species". International Journal of Development Research, 4(3): 769-775.

Eyer P (2002): "Environmental health issues". Environmental Perspective Supplements, 102: 56.

Farrow C (2002): "Hair dye and henna tattoo exposure". Emergency nurse, 10:10-23.

Filipic M, Zegura B, Sedmak B, et al., (2007): "Subchronic exposure of rats to sublethal dose of microcystin-YR induces DNA damage in multiple organs". Radiol Oncology, 41(1): 15-22.

Galiotte MP, Kohler P, Mussi G et al., (2008): "Assessment of occupational genotoxic risk among brazilian hairdressers". Ann Occup Hyg., 52 (7): 645-651.

Gude D, Bansal DP, Ambegaonkar R et al., (2012): "Paraphenylenediamine: Blackening more than just hair". Journal of Research in Medical Sciences, 17(6):584-586.

Jung P, Sesztak-Greinecker G, Wantke F, et al., (2006): "The extent of black henna tattoo's complications is not restricted to PPD-sensitization". Contact Dermatitis, 55(1):57.

Kang IK and Lee MH (2006): "Quantification of para-phenylenediamine and heavy metals in henna dye". Contact Dermatitis, 55:26-29.

Kawakubo Y, Merk HF, Masaoudi TA, et al., (2000): "N-Acetylation of paraphenylenediamine in human skin and keratinocytes". J Pharmacol Exp Ther., 292:150-155.

Kirkland DJ, Honeycombe JR, Lawler SD, et al., (1981): "Sister Chromatid exchanges before and after hair dyeing". Mut. Res., 90: 279-286.

Kirkland DJ, Lawler SD and Venitt S (1978):

"Chromosomal damage and hair dyes". Lancet, 15: 124-128

Mathur AK, Raizada RB, Srivastava MK et al., (2005): "Effect of Dermal Exposure to Paraphenylenediamine and Linear Alkylbenzene Sulphonate in Guinea Pigs". Biomed. Environ. Sci., 18:238240.

Meuling WA and DeBie AT (2009): “Consumer exposure to an actual, dark shade oxidative hair dye. A [14C]-PPD labeled mass balance study". TNO, Zeist, the Netherlands, Report No. 7852.

Nohynek GJ, Fautzb R, Benech-Kiefferc F et al., (2004): "Toxicity and human health risk of hair dyes". Food and Chemical Toxicology, 42:517-543.

Preston RJ, Skare JA and Aardema MJ (2009): “A review of biomonitoring studies measuring genotoxicity in humans exposed to hair dyes". Mutagenesis, 25:17-23.

Ram R, Swarnalatha G, Prasad N et al., (2007): "Para phenylenediamine ingestion; an uncommon cause of acute renal failure". Journal of postgrad Medicine, 53: 181182.

Sardas S, Aygün N and Karakaya AE (1997): "Genotoxicity studies on professional hair colorists exposed to oxidation hair dyes". Mutation Res., 394:153-161.

SCCP (2006) Scientific Committee on Consumer Products. "Opinion on pPhenylenediamine, COLIPA No. A7. 10 October, 2006". Available at: http://ec.europa.eu/ health/ph_risk/committees/.

Singh NP, Mccoy MT and Tice R (1988): A Simple Technique or Quantitation of Low Levels of DNA Damage in Individual Cell. Experimental Cell Research, 175: 184-191.

Skare JA, Nohynek GJ, Powrie R, et al., (2007): "Metabolism of oxidative hair dyes: an overview of in vivo, in vitro and clinical studies". Toxicol. Lett. 172: 31.

Stammberger I, Czich A and Braun K (2006): "Genotoxicity. In: Drug Discovery and Evaluation: Safety and Pharmacokinetic Assays, Vogel HG", (ed), 1st edition, Springer Science \& Business Media, Germany, pp: 828-840.

Sutrapu S, Jagadeeshwar K, Nagulu M et al., (2010): "Oxidative Stress and Antioxidant Status in hair dye poisoning". International Journal of pharmacognosy and phytochemical Research, 3(1):1-5.

Txilar N (2004): "Synthetic hair dye can mess you over! Available at: http://www.Hennaforhair.htm

Waggas AM (2011): "Neuro and Nephro-Toxicity in Rats Topically Treated with ParaPhenylene Diamine". American-Eurasian Journal of Toxicological Sciences, 3 (3): 130-137.

Yoshio T, Horiike N, Onji M, et al., (2003): Drug induced hepatitis due to repeated use of hair dye. Internal Med, 42:1104-1166. 


\title{
الملخص العربي
}

\section{تقييم السمية لحمض النووي الديوكسي ريبوزي لمادة بارافينيلين ديامين بعد الأستعمال الجلدي علي الفئران البالغة البيضاء}

\author{
أحمد السجيني و أماني السيد و هند الهلالي و ايمان عبد الحكيم
}

تستخدم صبغات الشعر على نطاق واسع كمستحضرات بتميل لتلوين الشعر الرمادي في جميع أنحاء العالم .

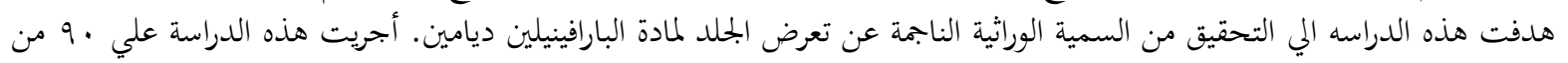

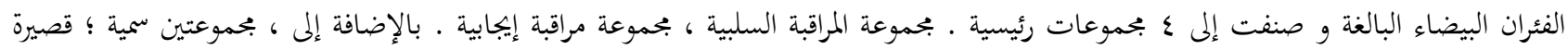
المدى و طويلة المدى.

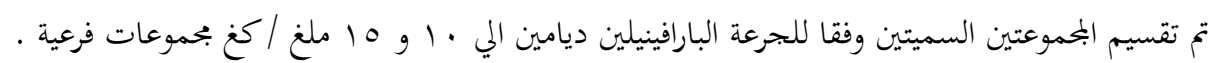

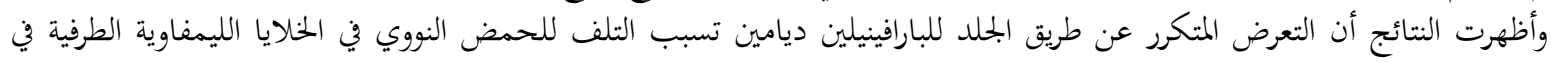

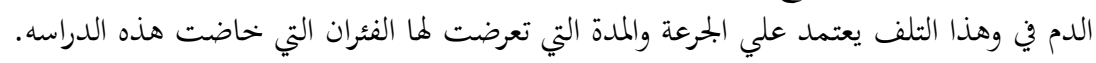
ا قسم الطب الثرعي والسموم الإكلينيكية - كلية الطب - جامعة عين شمس 